\section{Mens Rea}

Nathalie DeFabrique

Cook County Department of Corrections,

Chicago, IL, USA

\section{Synonyms}

Guilty mind

\section{Definition}

Mens rea is a Latin term used to describe the mental component of criminal responsibility. The concept of mens rea developed in England when judges decided that a criminal act alone in and of itself did not make an individual criminally responsible. The person is considered liable for the criminal act if during the offense he or she was believed to be in a guilty state of mind. If one is considered to be in a guilty state of mind, it supposes that the individual possessed knowledge of wrongfulness and a willingness to offend. In short, mens rea is the person's appreciation of the fact that the conduct was criminal. The concept of mens rea is the state of mind that the prosecution must prove that a defendant had when committing a crime.

\section{Cross-References}

- Actus Reas Diminished Capacity

- Insanity

Insanity Defense

Intent

\section{References and Readings}

Dubber, M. D. (2002). Criminal law: Model penal code. New York: Foundation Press.

Goldstein, A. M. (2003). Evaluation of criminal responsibility. In A. Goldstein (Ed.), Handbook of psychology (Vol. 11). Forensic psychology. Hoboken: Wiley.

Yates, K. F., \& Denney, R. L. (2008). Neuropsychology in the assessment of mental state at the time of the offense. In R. Denney \& J. Sullivan (Eds.), Clinical neuropsychology in the criminal forensic setting. New York: Guilford Press. 